\title{
MODULATION OF PHYSICO-CHEMICAL PROPERTIES OF BOVINE $\beta$-CASEIN BY NONENZYMATIC GLYCATION ASSOCIATED WITH ENZYMATIC DEPHOSPHORYLATION
}

\author{
M. DAREwiCZ, J. DZIUBA a , H. MioduszewsKa and P. MinKIEWICZ \\ Department of Food Biochemistry, Olsztyn University of Agriculture and Technology, \\ Plac Cieszyński 1, 10-726 Olsztyn-Kortowo. Poland
}

(Received: 29 March 1999; accepted: 7 June 1999)

\begin{abstract}
A major bovine casein fraction, $\beta$-casein was chemically glycated and/or enzymatically dephosphorylated. Ten glucose and nine lactose moieties were attached while all phosphate groups were removed. Glycation shifted the $\mathrm{pI}$ to acidic $\mathrm{pH}$ range and decreased the solubility at acidic $\mathrm{pHs}$ while dephosphorylation shifted the $\mathrm{pI}$ to neutral $\mathrm{pH}$ range and increased the solubility at acidic pHs. Dephosphorylation led to longer retention time measured using the reversed-phase high-performance liquid chromatography and affected UV-spectra of $\beta$-casein which suggested structural changes. Glycation did not affect these properties. Both modifications decreased the calcium sensitivity of $\beta$-casein, making it to keep $\alpha_{\mathrm{S} 1}$-casein in solution in the presence of $\mathrm{Ca}^{2+}$.
\end{abstract}

Keywords: $\beta$-casein, dephosphorylation, glycation, solubility, stabilization ability

The casein fraction of milk comprises four major proteins: $\alpha_{\mathrm{S1}^{-}} ; \alpha_{\mathrm{S} 2^{-}} ; \beta$ - and $\kappa$-casein. In comparison with typical globular proteins, such as the whey proteins the structures of the caseins are quite unique. Perhaps the most unusual feature is the amphiphilicity of their primary structure (SWAISGOOD, 1992).

$\beta$-Casein ( $\beta$-cn) consists of a polypeptide chain composed of 209 amino acids and has a molecular weight of $\sim 24 \mathrm{kDa}$ (SWAISGOOD, 1992). This protein is a flexible molecule with a polar head and unpolar tail. So the behaviour of $\beta$-cn is expected to be soap-like. A number of attempts have been made to alter physicochemical properties of proteins by chemical and enzymatic treatment (IMAFIDON et al., 1997). Non-enzymatic glycation (glycosylation) is the covalent binding of single sugars to $\alpha$ - or $\varepsilon$ - amino groups on proteins. In glycosylation catalysed by glycosyl transferases, short oligosaccharide chains become attached to asparagine, threonine or serine side chains through glycosidic bonds. In completely different, e.g. chemically-catalysed, glycation,

\footnotetext{
a To whom correspondence should be sent. Fax: (00 48 89) 52739 08, Phone: (00 48 89) 5233715
} 
sugars attack N-terminal amino acids or side chain lysine groups (FURTH, 1988). The preparation of neoglycoproteins by the covalent attachment of carbohydrates has been done to immobilize enzymes (KAMATA et al., 1990), to increase the heat stability of enzymes and inhibitors (MER et al., 1996) and to improve functional properties of proteins (WANISKA \& KINSELLA, 1984; KITABATAKE et al., 1985; COURTHAUDON et al., 1989; SAEKI, 1997). In all cases, better solubility was found for these carbohydratederived proteins.

Among the non-proteolytic enzymes acid and alkaline phosphatases have been used for casein modification. Dephosphorylation of casein micelles has been shown to lead to their disintegration and to reduce the formation of phosphopeptides (MEISEL \& SCHLIMME, 1995). Changes in solubility and decrease in calcium sensitivity were reported for whole casein by VAN HEKKEN and STRANGE (1993). The release of phosphate groups resulted in lower calcium sensitivity and softer curd during cheese making. LORENZEN and REIMERDES (1992) reported that the modification with alkaline and acid phosphatases increased the emulsion stability. In contrast, HUSBAND and coworkers (1997) showed a decrease in emulsion stability and an increase in foamability for dephosphorylated $\beta$-cn (dp- $\beta$-cn). Mild enzymatic and chemical treatments may have a beneficial effect on the physicochemical properties of $\beta$-casein.

In our earlier studies (DZIUBA et al., 1998; DAREWICZ et al., 1998) we reported about the changes of bovine $\beta$-cn upon 15-day of glycation with glucose. HENLE and KLOSTERMEYER (1993) reported that the reactivity of individual lysine residues for saccharide attack was extremely different, with Lys-28/29, Lys-32, Lys-99 and Lys-107 being preferably glycated. One of our intentions in this study was to increase the stabilizing properties of $\beta$-cn for $\alpha_{\mathrm{S} 1^{-}} \mathrm{cn}$ in the presence of $\mathrm{Ca}^{2+}$. By terminating the reaction of coupling the carbohydrates after $32 \mathrm{~h}$, we wanted the $\beta$-cn molecular status to be assimilated to $\kappa$-cn as the stabilizer for $\alpha_{\mathrm{S} 1}$ - $\mathrm{cn}$ fraction. The release of five phosphates from $\beta$-cn also may increase its stabilizing ability when $\mathrm{dp}-\beta-\mathrm{cn}$ is interacted with $\alpha_{\mathrm{S} 1}$-cn. The objective of our studies was to investigate the effects of these modifications (i.e. covalent attachment of saccharides and enzymatic release of phosphate groups) on solubility of modified proteins in media of different ionic strength and $\mathrm{pH}$. The chromatographic (reversed-phase high-performance liquid chromatography) and spectral (UV spectra) properties of modified proteins were also studied.

\section{Materials and methods}

\subsection{Materials}

Potato acid phosphatase [EC 3. 1. 3. 2.] was obtained from Boehringer Mannheim (Germany, cat. No. 108219). $\alpha$-D-Glucose and $\alpha$-D-lactose anhydrates were purchased 
from Merck (Darmstadt, Germany). Unless otherwise stated, all other chemicals were of analytical reagent grade obtained from Sigma (England) and Serva Feinbiochemica (Germany).

\subsection{Preparation of $\alpha_{s}$ - and $\beta$-casein}

The details of the casein fraction preparation were described earlier (DzIUBA et al., 1998; DAREWICZ et al., 1998). Briefly, the bovine casein was prepared from fresh skim milk from selected, homozygous at the four casein loci cow (genotype $\alpha_{\mathrm{S} 1}$-cn BB; $\beta$-cn $\mathrm{BB}$ and $\kappa-\mathrm{cn} \mathrm{AB}$ ) by isoelectric precipitation at $\mathrm{pH} 4.6$ (ANDREWS \& ALICHANIDIS, 1983). $\alpha_{S 1}$ - and $\beta$-Casein were prepared and purified by ion-exchange chromatography (THOMPSON, 1966). The purity of fractions was checked by isoelectric focusing (IEF) (see Section 1.6). The fractions were freeze dried. The protein content of the samples was estimated by Lowry's method using bovine serum albumin as a standard (LOWRY et al., 1965).

\subsection{Chemical modification of $\beta$-casein}

Samples were prepared by incubation of intact $\beta$-cn in $0.5 \mathrm{~mol}^{-1}$ glucose, galactose or lactose for $32 \mathrm{~h}$, at $37^{\circ} \mathrm{C}$, in $0.05 \mathrm{~mol} \mathrm{l}^{-1}$ phosphate buffer $(\mathrm{pH}$ 7.4) containing $3 \mathrm{mmol} \mathrm{l}^{-1}$ sodium azide. After dialysis against demineralized water, the fractions were freeze dried. The amount of sugars bound to proteins was quantified according to the procedure described by NESSAR and FURTH (1991).

\subsection{Enzymatic modification}

Intact and glycated $\beta$-cn were dephosphorylated with acid phosphatase. Samples $\left(10.0 \mathrm{mg} \mathrm{l}^{-1}\right)$ were incubated with enzyme at $20^{\circ} \mathrm{C}$ in $0.01 \mathrm{~mol} \mathrm{l}^{-1}$ imidazole buffer $(\mathrm{pH}$ 7.0). Maximally dephosphorylated samples were obtained by adding $0.05 \mathrm{U}$ of enzyme per $1 \mathrm{mg}$ of protein samples and incubating for $1 \mathrm{~h}$. The reaction was terminated by heating at $100{ }^{\circ} \mathrm{C}$ for $5 \mathrm{~min}$, after that the samples were dialyzed $(24 \mathrm{~h})$ against demineralized water and freeze dried. The degree of dephosphorylation was estimated by microscale colorimetric method according to IDF standard (FIL-IDF 1987) and Fiske-Subbarow method modified by BARTLETT (1959).

\subsection{Polyacrylamide gel electrophoresis}

SDS-PAGE was performed according to LAEMMLI (1970) in $12.5 \%(30.8 \% \mathrm{~T}$, $2.7 \% \mathrm{C}$ ) polyacrylamide gel slabs of $1 \mathrm{~mm}$ thickness. Protein bands were stained with Coomassie Brilliant Blue R-250. Additionally, we checked the effect of galactose binding on electrophoretic behaviour of $\beta$-cn. 


\subsection{Isoelectrofocusing analysis}

IEF was performed in $0.3 \mathrm{~mm}$ thick $8 \%$ polyacrylamide gel $(40 \% \mathrm{~T}, 3.9 \% \mathrm{C})$. An aliquot $(5 \mu \mathrm{l})$ of sample solutions containing $1.5 \mathrm{mg} \mathrm{ml}^{-1}$ casein, $8 \mathrm{~mol} \mathrm{l}^{-1}$ urea, $11 \%$ $(\mathrm{v} / \mathrm{v})$ glycerin and $3 \% 2$-mercaptoethanol were loaded into the gel. Whole casein, intact and completely dephosphorylated $\beta$-cn $\left(\mathrm{A}^{1} \mathrm{~A}^{2}\right)$ were used as standards. The values of $\mathrm{pI}$ of each sample before and after modification were determined according to SEIBERT and co-workers (1985).

\subsection{Reversed-phase high-performance liquid chromatography (RP-HPLC) and UV} spectroscopy

RP-HPLC analyses were performed using the Hewlett-Packard HP 1050 equipment with photodiode-array detector, linked to Hi-Pore RP $3184.6 \times 250 \mathrm{~mm}$ (Bio Rad Laboratories, USA). Chemstation A.03.03 program was used for data acquisition and processing. The solvent composition was as follows: acetonitrile (ACN):water:trifluoroacetic acid (TFA) 100:900:1 and 900:100:0.8 v/v/v in solvents A and B, respectively. ACN and TFA (J. T. Baker, The Netherlands) were of HPLC grade. The gradient of solvent $\mathrm{B}$ was from $27 \%$ to $42 \%$ during $20 \mathrm{~min}$. The protein concentration was c.a. $1.5 \mathrm{mg} \mathrm{ml}^{-1}$ in solvent A containing $6 \mathrm{~mol} \mathrm{l}^{-1}$ urea with $\mathrm{pH}=2.2$ adjusted using TFA. Injection volume was $100 \mu \mathrm{l}$. Other details of separations were described elsewhere (MINKIEWICZ et al., 1996). Apparent ratios of aromatic amino acids were calculated from the second-derivative UV spectra using the procedure described by PERRIN and co-workers (1995).

\subsection{Assessment of solubility}

$\beta$-Casein (intact and modified) samples were dissolved in demineralized water at $25^{\circ} \mathrm{C}$. The $\mathrm{pH}$ was adjusted with $0.1 \mathrm{~mol} \mathrm{l}^{-1} \mathrm{HCl}$ or $0.1 \mathrm{~mol} \mathrm{l}^{-1} \mathrm{NaOH}$. Final ionic strength was $0.1,0.5$ or $1 \mathrm{~mol} \mathrm{l}^{-1}$ (adjusted using $\mathrm{NaCl}$ ). An aliquot $(5 \mathrm{ml})$ of each sample was centrifuged for $15 \mathrm{~min} / 5000 \times \mathrm{g}$. Protein concentration in the resulting supernatant was determined by measuring the absorbance at $280 \mathrm{~nm}$ and calculating the concentration from standard curves made from diluted protein stock solution. Solubility was expressed as the percentage of protein in solution.

\section{9. $\mathrm{Ca}^{2+}$ sensitivity}

Stock solutions of $0.5 \% \beta$-cn (intact and modified) and $0.5 \% \alpha_{\mathrm{S} 1}$ - $\mathrm{cn}$ in 10 mmol $1^{-1}$ imidazole buffer ( $\mathrm{pH}$ 7.0) were prepared (VAN HEKKEN \& STRANGE, 1993). An aliquot $(5 \mathrm{ml})$ of stock solutions was adjusted with $1 \mathrm{~mol} \mathrm{l}^{-1} \mathrm{CaCl}_{2}$ to a $\mathrm{Ca}^{2+}$ 
concentration range from 0.0 to $30.0 \mathrm{mmol} \mathrm{l}^{-1}$. After centrifugation, the protein concentration in the supernatant was determined as described above.

\subsection{Ability of $\beta$-casein to stabilize $\alpha_{S 1}$-casein}

Stock solutions of $\alpha_{\mathrm{S}^{-}}$and $\beta$-cn were prepared as described in Section 1.9. The casein solutions were then mixed at $1: 1(\mathrm{v} / \mathrm{v})$ ratio. After $1 \mathrm{~h}$ of continuous stirring, the samples were incubated at $26{ }^{\circ} \mathrm{C}$ for $15 \mathrm{~min}$. Then the supernatant suspension was clarified with $0.1 \mathrm{~mol}^{-1}$ sodium citrate, and the samples were centrifuged at $3000 \times \mathrm{g}$ for $30 \mathrm{~min}$. The protein content of the supernatant was measured as described in section 1.8.

\subsection{Statistical analysis}

Statistical significance of differences was evaluated using the $t$-test.

\section{Results and discussion}

\subsection{Characterization of glycated and dephosphorylated $\beta$-casein}

It was found that 10 molecules of glucose and 9 molecules of lactose were bound to one molecule of $\beta$-cn. Under the conditions described in section Materials and methods, the percentage of glycosylated amino groups was $83 \%$ with glucose and $75 \%$ with lactose. These values are in good agreement with those found by COURTHAUDON and co-workers (1989) for covalent binding of glucosyl residues to whole casein. In all cases the samples were completely dephosphorylated $(100 \% \mathrm{dp})$. It could mean that even potential structural changes in $\beta$-cn after glycation did not hinder the approach of acid phosphatase to the susceptible bonds, which in turn led to the same result of dephosphorylation of intact and glycated $\beta$-cn.

\subsection{Effect of glycosylation and dephosphorylation on electrophoretic behaviour of $\beta$-casein}

The effects of glycation and dephosphorylation studied by polyacrylamide gel electrophoresis under denaturing conditions are presented in Fig. 1. The electrophoretic mobility was rather unmodified by the glycosylation and dephosphorylation. The glycated $\beta$-cn fraction bands were less stained probably because of their increased solubility (as discussed below) and decreased binding of Coomassie Brilliant Blue R250 by the lysyl residues, which are responsible for dye-protein interactions (DzIUBA \& MiodUSZEWSKA, 1997). Moreover, the lanes with dephosphorylated $\beta$-cn had bands additional to the main casein band. This may indicate a proteolytic activity of the acid phosphatase, resulting in peptide formation. LORENZEN and REIMERDES (1992) also reported on proteolytic activity of acid phosphatase resulting in the formation of 
hydrophobic peptides. These additional peptide bands were visible on the IEF electoropherograms. Binding of single sugar molecules suggests evident differences between the isoelectric points determined for intact, glycated and/or dephosphorylated $\beta$-cn. Table 1 shows the influence of glycation and dephosphorylation on $\mathrm{pI}$ values. The pI value determined for intact $\beta$-cn is in good agreement with the value found by SEIBERT and co-workers (1985). Glycation for $32 \mathrm{~h}$ slightly decreased the $\mathrm{pI}$ values for $\beta$-cn modified with glucose and lactose. This was due to a slight increase in the net negative charge of the $\beta$-cn molecule, since the attachement of saccharides replaced the positively charged $-\mathrm{NH}_{3}{ }^{+}$groups of lysine with uncharged sugar residues. Dephosphorylation of $\beta$-cn results in a decrease of the net negative charge of the Nterminal 50 amino acids at $\mathrm{pH} 7.0$ from -11 to -3 . Consequently the increase of $\mathrm{pI}$ of dephosphorylated $\beta$-cn was estimated. When both modifications were applied to $\beta$-cn, $\mathrm{pI}$ values were affected similarly as for dephosphorylated $\beta$-cn. The differences were significant at $\mathrm{P}<0.01$.

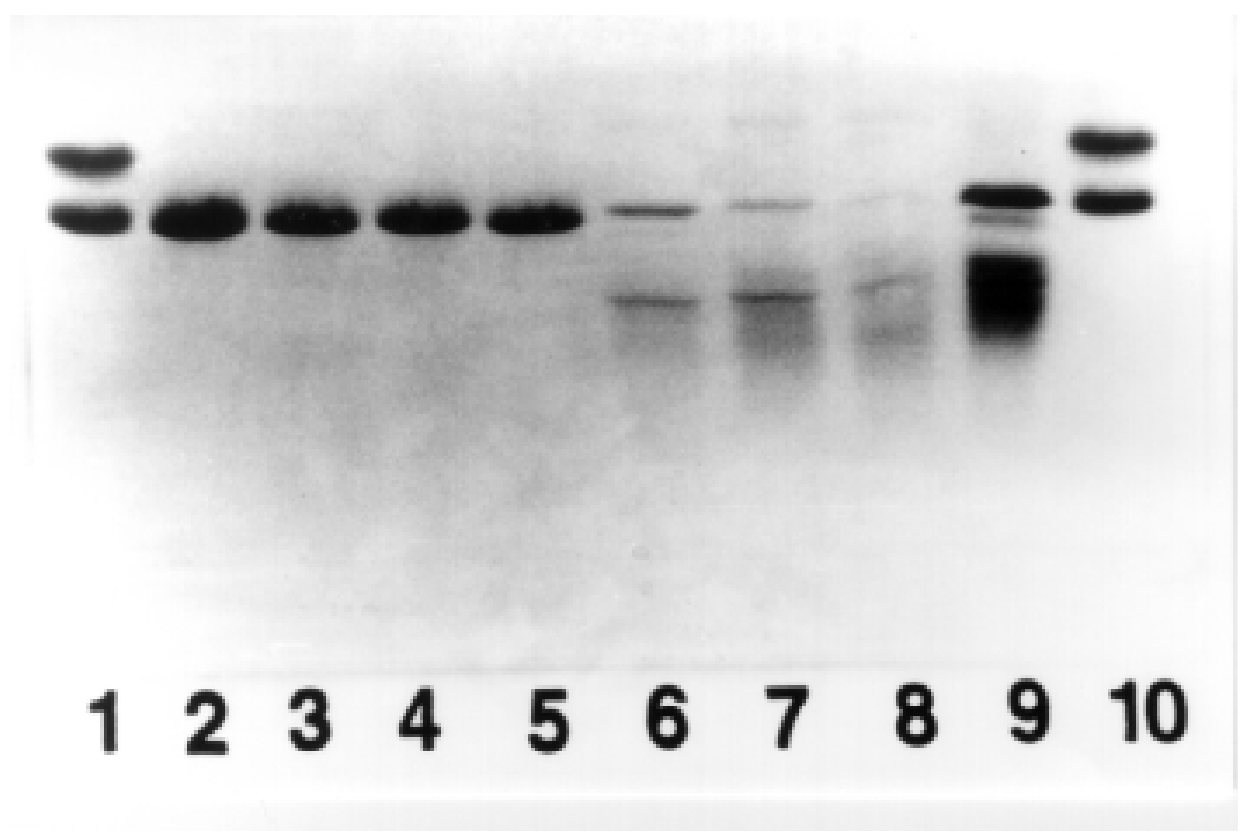

Fig. 1. Polyacrylamide gel electrophoresis of intact, glycated and dephosphorylated $\beta$-casein. For conditions see Materials and methods. 1: control (whole) casein; 2: intact $\beta$-casein $(-\mathrm{cn})$; 3: glucosylated $\beta$-cn; 4: galactosylated $\beta$-cn; 5: lactosylated $\beta$-cn; 6: glucosylated and dephosphorylated $\beta$-cn; 7: galactosylated and dephosphorylated $\beta$-cn; 8: lactosylated and dephosphorylated $\beta$-cn; 9: dephosphorylated $\beta$-cn; 10: control (whole) casein 
Table 1

The influence of glycation and dephosphorylation on pI values and solubility at the $p I$ of intact and modified $\beta$-casein ${ }^{a}$

\begin{tabular}{lcccc}
\hline Sample & $\begin{array}{c}\text { Mean } \\
\text { value of } \mathrm{pH} \\
\mathrm{n}=6\end{array}$ & $\begin{array}{c}\text { Standard deviation } \\
( \pm \mathrm{sd})\end{array}$ & $\begin{array}{c}\text { Corrected } \\
\mathrm{pI}^{\mathrm{c}}\end{array}$ & $\begin{array}{c}\text { Solubility } \\
(\%)^{\mathrm{d}}\end{array}$ \\
\hline Intact $\beta$-cn & 5.72 & 0.08 & 4.98 & $22 \pm 0.8$ \\
Glu- $\beta$-cn & 5.63 & 0.05 & 4.89 & $44 \pm 1.2$ \\
Lac- $\beta$-cn & 5.62 & 0.03 & 4.88 & $40 \pm 1.4$ \\
Dp- $\beta$-cn & 6.48 & 0.03 & 5.74 & $20 \pm 0.2$ \\
Dp-glu- $\beta$-cn & 5.36 & 0.04 & 5.62 & $42 \pm 0.9$ \\
Dp-lac- $\beta$-cn & 5.34 & 0.04 & 5.60 & $40 \pm 1.2$ \\
\hline
\end{tabular}

a For conditions see Materials and methods

${ }^{b}$ Key: $\beta$-casein ( $\beta$-cn); glucosylated $\beta$-casein (glu- $\beta$-cn); lactosylated $\beta$-casein (lac- $\beta$-cn); dephosphorylated $\beta$-casein (dp- $\beta$-cn); dephosphorylated and glucosylated $\beta$-casein (dp-glu- $\beta-\mathrm{cn})$; dephosphorylated and lactosylated $\beta$-casein (dp-lac- $\beta$-cn)

$\mathrm{c}^{\mathrm{C}}$ The error of urea $\mathrm{pH}$ value $(0.74)$

$\mathrm{d}$ Differences are significant at $\mathrm{P}<0.01$

\section{$2.3 R P-H P L C$}

Chromatograms of intact and dephosphorylated and glucosylated $\beta$-cn (dp-glu- $\beta$ cn) are presented in Fig. 2a and b. Dephosphorylated and lactosylated $\beta$-cn (dp-lac- $\beta$ cn) showed the same HPLC pattern as dp-glu- $\beta$-cn (data not shown). Intact $\beta$-cn, glucosylated $\beta$-cn (glu- $\beta$-cn) and lactosylated $\beta$-cn (lac- $\beta$-cn) had the same retention times (RT), (data not shown). BURR and co-workers (1996) have presented similar results for intact and lactosylated $\beta$-lactoglobulin. Dephosphorylation caused an increase of RT of sugar-free, glu- and lac- $\beta$-cn. This result is consistent with earlier results of MOLLÉ and LÉONIL (1995) as well as MINKIEWICZ and co-workers (1996), who found that RT of bovine caseinomacropeptide decreases with an increase of the number of phosphate groups. The peak with the RT value corresponding to this intact (phosphorylated) $\beta$-cn, indicated in Fig. $2 \mathrm{~b}$, can not be attributed to this protein, considering the fact that all phosphate groups were removed. We can rather suppose that it is a product of proteolysis. This may be supported by the SDS-PAGE and IEF results and the fact that RT of peptides with similar hydrophobicity decreases with the molecular weight according to the literature data (MANT et al., 1988). 

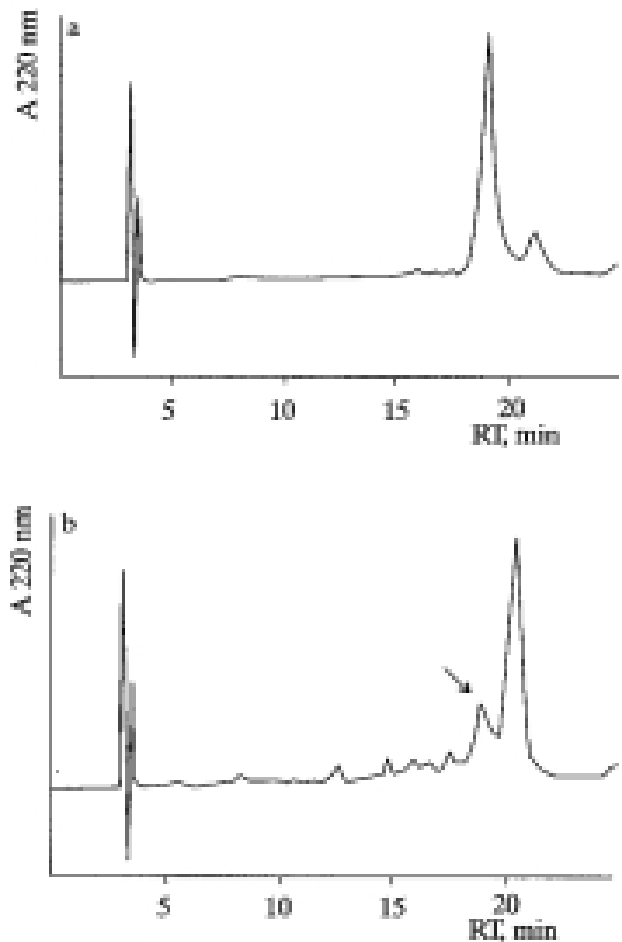

Fig. 2. The RP-HPLC chromatogram of intact (a) and lactosylated and dephosphorylated $\beta$-casein (b). For conditions see Materials and methods. Arrow indicates the peak with the retention time (RT) corresponding to intact $\beta$-casein

\subsection{Second-derivative UV spectra}

The second-derivative UV spectrum of dp-glu- $\beta$-cn is presented in Fig. 3. It was possible to measure accurately the apparent tryptophan/phenylalanine and tyrosine/phenylalanine molar ratios only for peaks of $\beta$-cn and dp- $\beta$-cn (both sugar-free and glycated). Other peaks have too low ratio of absorbances at the top of peak and at the saddle. The minima corresponding to aromatic amino acid residues, present within the range given by GREGO and co-workers (1986), were taken into consideration. The observed Trp/Phe ratios were $0.106(\mathrm{sd}= \pm 0.006 ; \mathrm{n}=4)$ and $0.115(\mathrm{sd}= \pm 0.013 ; \mathrm{n}=4)$ for $\beta$-cn (including glycated forms) and dp- $\beta$-cn (including glycated forms), respectively. There were statistically significant differences in the apparent $\mathrm{Trp} / \mathrm{Phe}$ ratio between phosphorylated and dephosphorylated $\beta$-cn as well as between apparent ratios and true ratio for $\beta$-cn (0.111) calculated from the amino acid composition (SWAISGOOD, 1992). 


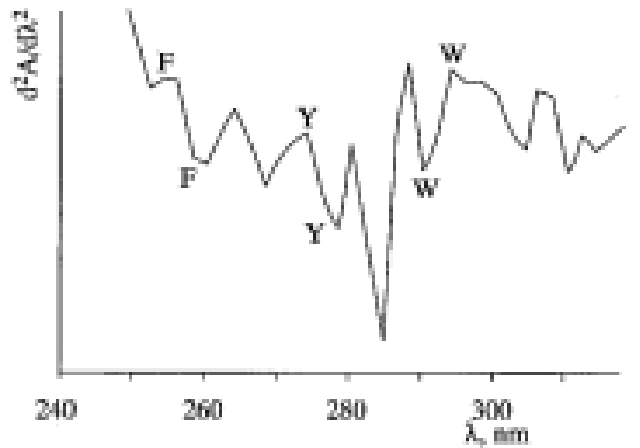

Fig. 3. The second-derivative UV spectrum of intact $\beta$-casein. For conditions see Materials and methods. F, $\mathrm{Y}, \mathrm{W}$ : minima and maxima corresponding to phenylalanine, tyrosine and tryptophan, respectively

The observed Tyr/Phe ratios were: $0.35(\mathrm{sd}= \pm 0.07 ; \mathrm{n}=4)$ and $0.54(\mathrm{sd}= \pm 0.06 ; \mathrm{n}=4)$ for $\beta$-cn (including glycated forms) and dp- $\beta$-cn (including glycated forms), respectively. There were differences at $\mathrm{P}<0.01$ between $\beta$-cn and dp- $\beta$-cn, respectively, as well as between both forms and the true ratio $(0.44)$ at $\mathrm{P}<0.05$. Glycation did not cause changes in the UV spectra. Second-derivative UV spectra reflect the amino acid composition of oligopeptides (PERRIN et al., 1995). In the case of proteins, the differences between second derivative of absorbance at the maxima and minima may also depend on the structure of proteins and solvent accessibility of individual aromatic amino acid residues (MACH \& MIDDAUGH, 1994). In our case, the observed changes in UV spectra may be explained by the sensitivity of spectral properties of the tyrosine residues to the structural changes in $\beta$-cn particle caused by dephosphorylation. Our results differ from those reported by $\mathrm{MACH}$ and MidDAUGH (1994). These authors found that the magnitude of peaks corresponding to Trp residues was more sensitive to the structural changes and environment than that corresponding to Tyr residues, but their experiments were performed in water solutions and in mixtures containing ethanol or polyethylene glycol in neutral $\mathrm{pH}$. Our spectra were collected in highly acidic ACN: water mixtures used for RP-HPLC separations. Moreover, UV spectra of $\beta$-cn forms could be affected by the irreversible structural changes caused by the interactions of protein with urea during sample preparation. The influence of urea on protein spectral properties was observed by BOBE and co-workers (1998).

\subsection{Effect of glycosylation and dephosphorylation on the solubility of $\beta$-casein}

The covalent attachment of glucosyl or lactosyl residues to $\beta$-casein improved the solubility in the $\mathrm{pH}$ range of isoelectric points (Table 1). Changes in the solubility of 
glycated fractions can be caused by the production of the steric hindrance of the $\beta$-cn molecule. It leads to higher electrostatic repulsion between the modified molecules. Removing five phosphate groups from $\beta$-casein causes a decrease in the net negative charge of the molecule and consequently decreases the solubility in the $\mathrm{pH}$ range of isoelectric point, as compared to the intact molecule. It is due to a decrease in the hydrophilicity, electrostatic repulsive forces and steric repulsion between the dephosphorylated molecules. Dephosphorylation of $\beta$-cn samples modified with glucose and lactose did not alter their solubility, as compared to glu- and lac- $\beta$-cn.

The effect of $\mathrm{pH}$ range from 2.0 to 8.0 and ionic strength $0.0,0.1,0.5$ and 1.0 on the $\beta$-cn samples solubility is shown in Tables $2-5$. Generally, in all cases, when the ionic strength increased, solubility also increased at the $\mathrm{pH}$ range of the isoelectric points. This phenomenon is due to the well known salting-in effect which decreases the electrostatic attractions between molecules and competition of $\mathrm{Na}^{+}$with protons. For intact $\beta$-cn, the solubility was slightly decreased at the acidic $\mathrm{pH}$ range when ionic strength increased. For glu- and lac- $\beta$-cn (results not shown, tendency the same as for glu- $\beta$-cn) the solubility increased at neutral and alkaline $\mathrm{pH}$ ranges, while it decreased at acidic $\mathrm{pH}$ range. Dephosphorylation significantly increased the solubility of $\beta$-cn molecules at acidic $\mathrm{pH}$ range and ionic strengths used. It caused however, slight decrease in solubility of $\mathrm{dp}-\beta-\mathrm{cn}$ at neutral and alkaline $\mathrm{pH}$ ranges. Similar trends in behaviour of modified casein molecule in solutions at different $\mathrm{pH}$ and ionic strength was observed by COURTHAUDON and co-workers (1989) as well as VAN HEKKEN and STRANGE (1993). Dephosphorylation associated with glycation increased the solubility of the samples in the whole $\mathrm{pH}$ range, as compared to both intact and dp- $\beta$-cn samples. Generally, the improvement in the solubility can be attributed to the introduction of saccharide residues onto the $\beta$-cn molecule. The solubility of a protein has been reported to be a manifestation of the equilibrium between protein-solvent and proteinprotein interactions (KINSELLA et al., 1985). Therefore, the attachment of hydrophilic carbohydrate moieties shifts the equilibrium away from protein-protein interactions and enhances solubility of the $\beta$-cn molecule. On the other hand the removal of the hydrophilic phosphate groups creates circumstances unfavoured for protein-solvent interactions (KINSELLA et al., 1985). In this case it seems that protein-protein interactions are increased more than protein-solvent interactions. It could lead to aggregation or even precipitation of modified $\beta$-cn molecule. 
Table 2

Effect of $p H$ and ionic strength on the solubility, \% $( \pm S D)$ of intact $\beta$-casein ${ }^{a}$

\begin{tabular}{ccccc}
\hline & \multicolumn{4}{c}{ Ionic strength } \\
\cline { 2 - 5 } $\mathrm{pH}$ & 0.0 & 0.1 & 0.5 & 1.0 \\
\hline 2.0 & $65.1 \pm 0.3$ & $76.0 \pm 0.8$ & $61.0 \pm 0.4$ & $60.0 \pm 4.2$ \\
3.0 & $76.4 \pm 0.4$ & $77.0 \pm 1.8$ & $66.0 \pm 0.5$ & $66.0 \pm 0.4$ \\
4.0 & $58.0 \pm 1.2$ & $63.0 \pm 3.2$ & $56.0 \pm 0.5$ & $57.0 \pm 0.4$ \\
5.0 & $20.0 \pm 1.7$ & $31.0 \pm 0.4$ & $40.0 \pm 1.2$ & $40.0 \pm 4.6$ \\
6.0 & $81.0 \pm 1.2$ & $88.0 \pm 1.0$ & $80.0 \pm 0.4$ & $77.0 \pm 1.9$ \\
7.0 & $76.0 \pm 0.7$ & $91.0 \pm 1.5$ & $82.0 \pm 1.2$ & $75.0 \pm 0.8$ \\
8.0 & $77.0 \pm 1.5$ & $90.0 \pm 1.0$ & $81.0 \pm 1.9$ & $75.0 \pm 0.2$ \\
\hline
\end{tabular}

$a^{a}$ For conditions see Materials and methods

Table 3

Effect of $p H$ and ionic strength on the solubility, $\%\left( \pm\right.$ SD) of glucosylated $\beta$-casein ${ }^{a}$

\begin{tabular}{ccccc}
\hline & \multicolumn{4}{c}{ Ionic strength } \\
\cline { 2 - 4 } $\mathrm{pH}$ & 0.0 & 0.1 & 0.5 & 1.0 \\
\hline 2.0 & $80.0 \pm 1.6$ & $78.0 \pm 0.3$ & $69.0 \pm 0.6$ & $70.0 \pm 1.1$ \\
3.0 & $73.0 \pm 0.1$ & $55.0 \pm 1.3$ & $58.0 \pm 0.7$ & $58.0 \pm 0.5$ \\
4.0 & $49.0 \pm 0.6$ & $50.0 \pm 0.3$ & $56.0 \pm 0.4$ & $54.0 \pm 0.5$ \\
5.0 & $44.0 \pm 1.5$ & $49.0 \pm 0.7$ & $50.0 \pm 0.4$ & $52.0 \pm 0.7$ \\
6.0 & $78.0 \pm 0.8$ & $79.0 \pm 0.6$ & $85.0 \pm 1.1$ & $85.0 \pm 0.3$ \\
7.0 & $90.5 \pm 0.4$ & $100.0 \pm 2.3$ & $90.0 \pm 1.1$ & $99.0 \pm 0.4$ \\
8.0 & $90.0 \pm 1.0$ & $90.0 \pm 0.8$ & $99.0 \pm 0.2$ & $100.0 \pm 0.7$ \\
\hline
\end{tabular}

a For conditions see Materials and methods

\subsection{Effect of $\beta$-casein glycation and dephosphorylation on its and $\alpha_{S 1}$-casein $\mathrm{Ca}^{2+}$ sensitivity}

The $\mathrm{Ca}^{2+}$ solubility curves for intact, glycated and dephosphorylated $\beta$-cn and $\beta$ cn associated with $\alpha_{\mathrm{S} 1}$-cn in solution are presented in Figs 4 and 5, respectively. The solubility of intact $\beta$-cn decreased significantly between 0 and $7 \mathrm{mmol}^{-1} \mathrm{Ca}^{2+}$. 
Table 4

Effect of $p H$ and ionic strength on the solubility, \% ( \pm SD) of dephosphorylated $\beta$-casein ${ }^{a}$

\begin{tabular}{ccccc}
\hline & \multicolumn{4}{c}{ Ionic strength } \\
\cline { 2 - 5 } $\mathrm{pH}$ & 0.0 & 0.1 & 0.5 & 1.0 \\
\hline 2.0 & $78.0 \pm 0.1$ & $89.0 \pm 0.3$ & $90.0 \pm 0.8$ & $88.0 \pm 0.4$ \\
3.0 & $77.0 \pm 0.8$ & $85.0 \pm .03$ & $79.0 \pm 0.4$ & $85.0 \pm 0.3$ \\
4.0 & $78.0 \pm 0.1$ & $78.0 \pm 0.2$ & $72.0 \pm 0.1$ & $77.0 \pm 0.8$ \\
5.0 & $22.0 \pm 0.3$ & $32.0 \pm 0.5$ & $48.0 \pm 1.7$ & $42.0 \pm 0.2$ \\
6.0 & $64.0 \pm 0.2$ & $59.0 \pm 1.3$ & $60.0 \pm 0.4$ & $58.0 \pm 0.6$ \\
7.0 & $72.0 \pm 0.4$ & $64.0 \pm 0.7$ & $68.0 \pm 0.5$ & $76.0 \pm 0.1$ \\
8.0 & $80.0 \pm 1.3$ & $76.0 \pm 0.3$ & $78.0 \pm 0.6$ & $70.0 \pm 0.9$ \\
\hline
\end{tabular}

${ }^{a}$ For conditions see Materials and methods

Table 5

Effect of $p H$ and ionic strength on the solubility, $\%( \pm S D)$ of dephosphorylated and glucosylated $\beta$-casein ${ }^{a}$

\begin{tabular}{ccccc}
\hline & \multicolumn{4}{c}{ Ionic strength } \\
\cline { 2 - 5 } $\mathrm{pH}$ & 0.0 & 0.1 & 0.5 & 1.0 \\
\hline 2.0 & $89.0 \pm 1.2$ & $97.0 \pm 0.6$ & $98.0 \pm 0.2$ & $99.0 \pm 0.3$ \\
3.0 & $90.0 \pm 1.5$ & $98.0 \pm 0.2$ & $99.0 \pm 0.9$ & $97.0 \pm 1.1$ \\
4.0 & $79.0 \pm 0.1$ & $93.0 \pm 1.1$ & $88.0 \pm 0.4$ & $92.0 \pm 0.2$ \\
5.0 & $40.0 \pm 1.7$ & $53.0 \pm 1.2$ & $54.0 \pm 1.4$ & $55.0 \pm 0.4$ \\
6.0 & $69.0 \pm 0.2$ & $90.0 \pm 2.5$ & $95.0 \pm 0.4$ & $97.0 \pm 0.5$ \\
7.0 & $82.0 \pm 0.5$ & $91.0 \pm 0.9$ & $93.0 \pm 1.2$ & $96.0 \pm 2.2$ \\
8.0 & $83.0 \pm 0.6$ & $90.0 \pm 1.8$ & $92.0 \pm 1.7$ & $97.0 \pm 1.3$ \\
\hline
\end{tabular}

${ }^{a}$ For conditions see Materials and methods

Then reversal of solubility was detected up to $30 \mathrm{mmol}^{-1} \mathrm{Ca}^{2+}$. This behaviour can be due to the presence of carboxyl groups. Binding the $\mathrm{Ca}^{2+}$ can reverse their charge or displace a proton to produce a charged group. The appearance of electrostatic repulsion can prevent the $\beta$-cn molecule from polymerization and precipitation. The phenomenon of solubility reversal was observed for all our samples. Dephosphorylation caused the 


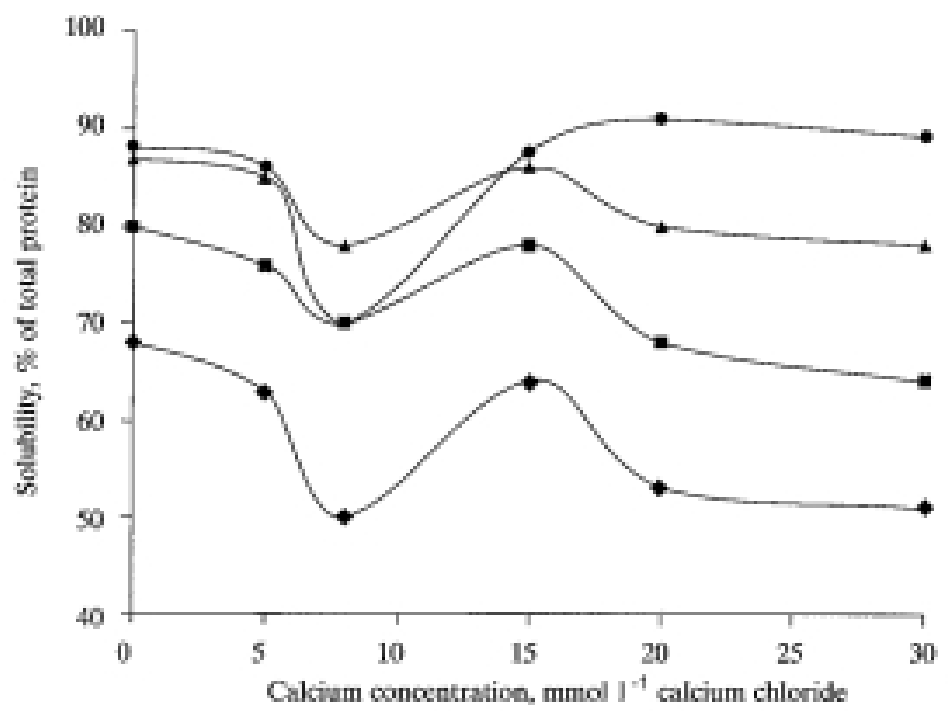

Fig. 4. Effect of $\mathrm{Ca}^{2+}$ concentration on the solubility of intact, glucosylated and/or dephosphorylated $\beta$-casein. $\bullet$ : intact $\beta$-casein; $\boldsymbol{\bullet}$ : glucosylated $\beta$-casein; $\mathbf{\square}$ : dephosphorylated $\beta$-casein; $\boldsymbol{\Delta}$ : glucosylated and dephosphorylated $\beta$-casein. For conditions see Materials and methods. Maximum standard deviation (SD) was \pm 1.85

calcium sensitivity of $\beta$-cn to be decreased. Similar result was observed for glu- and lac$\beta$-cn (result similar to the first one, not shown), but at a higher percentage of protein in solution. This may be due to the higher solubility of glycated $\beta$-cn, as compared to dephosphorylated one. This is the only way we can explain the lowest calcium sensitivity of glycated samples which still contain phosphate groups. Such explanation can be supported by the results obtained for glycated and dephosphorylated samples. Removal of negative phosphate groups, which are the binding sites for $\mathrm{Ca}^{2+}$, decreases the association of $\beta$-cn molecule in solution. So the dp- $\beta$-cn is less likely to form a micelle and is better soluble in the presence of $\mathrm{Ca}^{2+}$. In the presence of the $\alpha_{\mathrm{S} 1^{-}} \mathrm{cn}$ in solution the $\mathrm{Ca}^{2+}$-independent dp- $\beta$-cn can protect the first one against the calcium precipitation. Because $\beta$-cn still possesses the amphiphilic structure, it can associate with $\alpha_{\mathrm{S} 1}$-cn and, in this way, is free in solution. Glycation can deepen the behaviour of the molecule presented above by increasing the solubility of $\beta$-cn. 


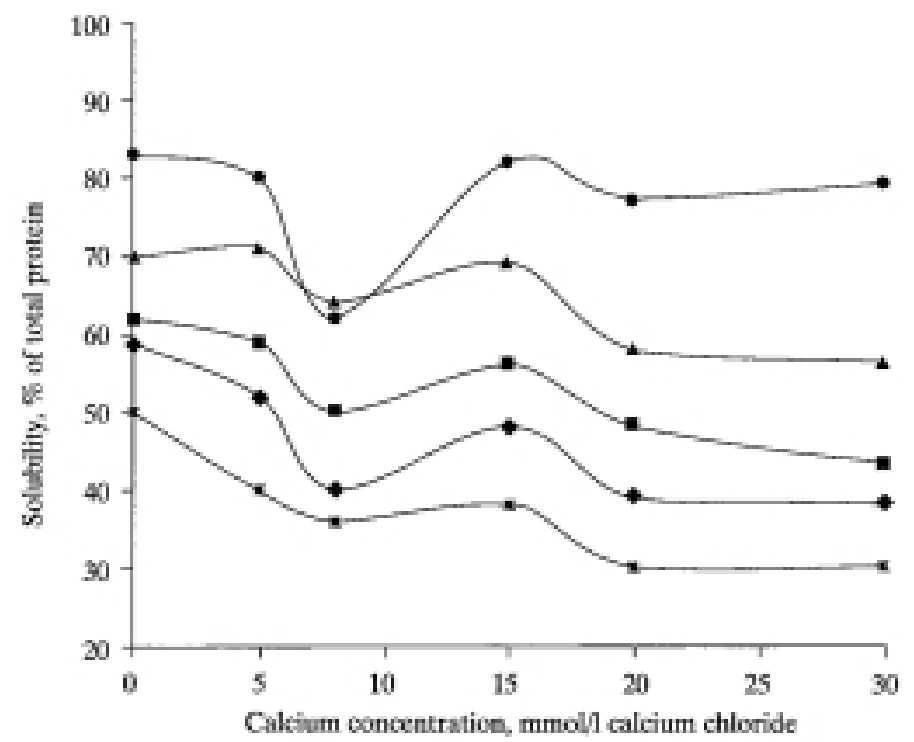

Fig. 5. Effect of $\mathrm{Ca}^{2+}$ concentration on the solubility of intact, glucosylated and/or dephosphorylated $\beta$-casein associated with $\alpha_{\mathrm{s} 1}$-casein. $\bullet$ : intact $\beta$-casein with $\alpha_{\mathrm{s} 1}$-casein; $\bullet$ : glucosylated $\beta$-casein with $\alpha_{\mathrm{s} 1}$-casein; $\boldsymbol{\square}$ : dephosphorylated $\beta$-casein with $\alpha_{\mathrm{s} 1}$-casein; $\boldsymbol{\Delta}$ : glucosylated and dephosphorylated $\beta$-casein with $\alpha_{\mathrm{s} 1}$-casein; $*$ : $\alpha_{\mathrm{s} 1}$-casein; For conditions see Materials and methods. Maximum standard deviation (SD) was \pm 1.66

\section{Conclusions}

Binding of carbohydrate moieties with $\beta$-casein through glycation increased the interactions between the protein and polar environment, shifting the $\mathrm{pI}$ value to the acid $\mathrm{pH}$ range and leading to increased solubility. Dephosphorylation increased the retention time measured using RP-HPLC and changed the spectral properties of $\beta$-cn. Glycation did not affect the RP-HPLC patterns as well as the second-derivative UV spectra of protein. It suggests that dephosphorylation caused changes in the structure of peptide backbone of $\beta$-casein. The removal of charged phosphate groups shifted the $\mathrm{pI}$ value to the neutral $\mathrm{pH}$ range and decreased the solubility of $\beta$-cn. On the other hand both treatments significantly altered the solubility of $\beta$-cn. Moreover, both modifications (alone or combined) decreased the calcium sensitivity of $\beta$-cn, making it to keep $\alpha_{\mathrm{S} 1^{-}} \mathrm{cn}$ in solution in the presence of $\mathrm{Ca}^{2+}$. All these modifications should also appreciably 
modify other functional properties, but the data concerning the foaming and emulsifying properties of modified $\beta$-cn are now being prepared. To investigate the modified $\beta$-cn structure-function relationship in more detail we will focuse in our future studies on the secondary structure of $\beta$-cn in solution and adsorbed state.

This work was supported by funds of KNB. (Project: 5P06g 010 16).

\section{References}

ANDREWS, A. T. \& ALICHANIDIS, E. J. (1983): Proteolysis of caseins and the proteose-peptone fraction of bovine milk. J. Dairy Res., 50, 275-290.

BARTLETT, G. R. (1959): Phosphorus assay in column chromatography. J. biol. Chem., 234, 466-486.

BOBE, G., BEITZ, D. C., FREEMAN, A. E. \& LINDBERG, G. L. (1998): Sample preparation affects separation of whey proteins by reversed-phase high-performance liquid chromatography. J. agric. Fd Chem., 46, 1321-1325

BURR, R., MOORE, C. H. \& HILL, J. P. (1996): Evidence of multiple glycosylation of bovine $\beta$-lactoglobulin by electrospray ionization mass spectrometry. Milchwissenschaft, 51, 488-493.

COURTHAUDON, J. L., COLAS, B. \& LORIENT, D. (1989): Covalent binding of glucosyl residues to bovine casein: effect on solubility and viscosity. J. agric. Fd Chem., 37, 32-36.

DAREWICZ, M., DZIUBA, J. \& MiODUSZEWSKA, H. (1998): Some physicochemical properties and structural changes of bovine $\beta$-casein upon glycation. Nahrung, 42, 213-214.

DZIUBA, J. \& MIODUSZEWSKA, H. (1997): Quantitative analysis of milk proteins by SDS-PAGE method. Pol. J. Fd Nutr. Sci., 6/47 (1), 91-98.

DZIUBA, J., DAREWICZ, M. \& MIODUSZEWSKA, H. (1998): Physico-chemical characteristics of different genetic variants of bovine $\beta$-casein, modified covalently by glucose, galactose and lactose. Pol. $J$. Fd Nutr. Sci., 7/48 (S), 168-171.

FIL-IDF (1987): Determination of total phosphorus content in cheese. Standard No. 33C.

FURTH, A. (1988): Methods for assaying nonenzymatic glucosylation. A review. Anal. Biochem., 175, 347-360.

GREGO, B., NiCE, E. C. \& SIMPSON, R. J. (1986): Use of scanning diode array detector with reversed-phase microbore columns for the real-time spectral analysis of aromatic amino acids in peptides and proteins at the submicrogram level. J. Chromat., 352, 359-368.

HENLE, T. \& KLOSTERMEYER, H. (1993): The reactivity of the individual protein bound lysine residues of $\beta$ casein $\mathrm{A}^{1}$ during the initial stages of the Maillard-reaction. IDF Spec. Iss. 9303, 183-189.

HuSBAND, F. A., WILDE, P. J., MACKIE, A. R. \& GARWOOD, M. J. (1997): A comparison of the functional and interfacial properties of $\beta$-casein and dephosphorylated $\beta$-casein. J. Coll. Interf. Sci., 195, 77-85.

IMAFIDON, G. I., FARKYE, N. Y. \& SPANIER, A. M. (1997): Isolation, purification and alteration of some functional groups of major milk proteins. A review. Crit. Rev. Fd Sci. Nutr., 37, 663-689.

KAMATA, Y., KUROTA, A. \& YAMAUCHI, F. (1990): Enzyme immobilization on glycosylated edible proteins. Agric. biol. Chem., 54, 3049-3050.

Kinsella, J. E., DAMODARAN, S. \& GERMAN, B. (1985): Physicochemical and functional properties of oilseed proteins with emphasis on soy proteins. New Protein Foods, 5, 107-179. 
KitabataKe, N., CuQ, J. L. \& CheFtel, J. C. (1985): Covalent binding of glucosyl residues to betalactoglobulin: effects on solubility and heat stability. J. agric. Fd Chem., 33, 125-130.

LAEMMLI, U. K. (1970): Cleavage of structural proteins the assembly of the head of bacteriophage T4. Nature, 277, 1738-1745.

LORENZEN, P. \& REIMERDES, E. H. (1992): Enzymatic dephosphorylation of caseins and creaming behaviour of o/w emulsions stabilized with dephosphorylated casein fractions. Nahrung, 36, 595-599.

LOWRY, O. H., ROSEBROUGH, N. J., FARR, A. J. \& RANDALl R. J. (1965): Protein measurement with the Folin phenol reagent. J. biol. Chem., 193, 265-275.

MACH, H. \& MIDDAUGH, R. (1994): Simultaneous monitoring of the environment of tryptophan, tyrosine and phenylalanine residues in proteins by near-ultraviolet second-derivative spectroscopy. Anal. Biochem., 222, 323-331.

MANT, C. T., BURKE, T. W., BLACK, A. \& HODGES J. (1988): Effect of peptide chain length on peptide retention behaviour in reversed-phase chromatography. J. Chromat., 458, 193-205.

MEISEL, H. \& SCHLIMME, E. (1995): Kasein-gebundener Phosphor und der Gehalt am freien Aminosäuren in unterschiedlich wärmebehandelter Milch. Kieler Milchw. Forsch., 47, 289-295.

MER, G., HIETER, H. \& LEFEVRE, J.-F. (1996): Stabilization of proteins by glycosylation examined by NMR analysis of a fucosylated proteinase inhibitor. Nature Struct. Biol., 3, 145-152.

MinKIEWICZ, P., SlANGEN, C. J., LAGERWERF, F. M., HAVERKAMP, J., ROLIEMA, H. S. \& VISSER, S. (1996): Reversed-phase high performance liquid chromatographic separation of bovine $\kappa$-casein macropeptide and characterization of isolated fraction. J. Chromat. A, 743, 123-135.

MOLLÉ, D. \& LÉONIL, J. (1995): Heterogeneity of bovine K-casein caseinomacropeptide, resolved by liquid chromatography on-line with electrospray ionization mass spectrometry. J. Chromat. A, 708, 223-230.

NESSAR, A. \& FURTH, A. (1991): A microassay for protein glycation based in periodate method. Anal. Biochem., 192, 109-111.

PERRIN, E., MiClO, L., DRIOU, A. \& LINDEN, G. (1995): Rapid determination of the ratios of three aromatic residues in peptides by reversed-phase high performance liquid chromatography with a high resolution photodiode-array detector. J. Chromat. B, 664, 267-276.

SAEKI, H. (1997): Preparation of neoglycoprotein from carp myofibrillar protein by Maillard reaction with glucose. J. agric. Fd Chem., 45, 680-684.

SEIBERT, B., ERHARDT, G. \& SENFT, B. (1985): Procedure for simultaneous phenotyping of genetic variants in cow's milk by isoelectric focusing. Anim. Blood Groups Biochem. Genet., 16, 183-191.

SWAISGOOD, H. E. (1992): Chemistry of the caseins. - in: FoX, P. F. (Ed.). Advanced dairy chemistry - Vol. 1 Proteins. Elsevier Applied Science Publishers, London - New York, pp 63-110.

THOMPSON, M. P. (1966): DEAE 52-cellulose-urea chromatography of casein in the presence of 2mercaptoethanol. J. Dairy Sci., 49, 792-795.

VAN HEKKEN, D. L. \& STRANGE, E. D. (1993): Functional properties of dephosphorylated bovine whole casein. J. Dairy Sci., 76, 3384-3391.

WANISKA, R. D. \& KinSELLA, J. E. (1984): Physicochemical properties of maltosyl and glucosaminyl derivatives of beta-lactoglobulin. Int. J. Pept. Prot. Res., 23, 467-476. 